\title{
Copper(II)quenched oligonucleotide probes for fluorescent DNA sensing
}

\section{Jens Brunner and Roland Kraemer*}

\section{Supplementary material}

\section{Figure Captions}

Scheme 1: Solid-phase syntheses of oligo 1, 2, 3

Scheme 2: Synthesis of oligo 4

Figures 1, 2, 3, 4: MALDI-TOF spectra of DNA 1, 2, 3 and $\mathbf{4}$ are given

General remarks: The solution of $50 \%$ saturated 6-aza-2-thiothymine in acetonitrile and $50 \% 0.1 \mathrm{M}$ diammoniumcitrate in water was used as a matrix for MALDI-TOF analysis of the DNA conjugates. MALDI-TOF mass spectra were recorded on a Bruker BIFLEX III spectrometer.

Figure 5: Fluorescence recovery of $\mathrm{Cu}(\mathrm{II})$ quenched 1 by competing ligand 1,2-diaminoethane General remarks: The fluorescence experiments were done on a Varian Eclipse Fluorescence Spectrophotometer with a Hellma $50 \mu$ l fluorescence cuvette. The exitation wavelength was $\lambda=494 \mathrm{~nm}$, spectra were obtained from $\lambda=500$ to $600 \mathrm{~nm}$.

Figure 6: Fluorescence of $\mathrm{Cu}(\mathrm{II})$ quenched oligo 2 on addition of complementary DNA 1

Figures 7, 8, 9, 10: Fluorimetric titrations of oligo 1, oligo 2, oligo 3 and oligo 4 with $\mathrm{Cu}(\mathrm{II})$

General remarks: The fluorescence experiments were done on a Varian Eclipse Fluorescence Spectrophotometer with a Helma $50 \mu$ l fluorescence cuvette. The exitation wavelength was $\lambda=494 \mathrm{~nm}$, spectra were obtained from $\lambda=500$ to $600 \mathrm{~nm}$. The pyrene modified oligo 4 was excited at $\lambda=340 \mathrm{~nm}$ and spectra were obtained from $\lambda=350$ to $550 \mathrm{~nm}$.

Figures 11, 12: Comparison of optical and fluorescence spectra of oligo 1 and of calcein on titration with $\mathrm{Cu}(\mathrm{II})$

General remarks: The UV-Vis absorption measurements were done on a Varian Cary 100 Bio Spectrophotometer. The fluorescence experiments were done on a Varian Eclipse Fluorescence Spectrophotometer. The exitation wavelength was $\lambda=494 \mathrm{~nm}$, spectra were obtained from $\lambda=500$ to $600 \mathrm{~nm}$. Titration experiments were performed with a $50 \mu \mathrm{l}$ fluorescence cuvette for oligo 1 and a $1000 \mu$ fluorescence cuvette for Calcein. 




PG: Cytidine - benzoyl protected

Adenosine - benzoyl protected

Guanosine - isobutyryl protected

Scheme 1: Synthesis of oligo 1, 2, 3; the 3'-fluorescein-5'- MMT protected aminolink hairpin-DNA on a CPG solid support was purchased from Metabion, Planegg-Martinsried (Germany). 1-Hydroxybenzotriazole (HOBT) was purchased from Acros Organics and O(Benzotriazol-1-yl)-N,N,N',N'-tetramethyluronium hexafluorphosphate (HBTU) was purchased from Fluka. The Ligand 2,2'-Bipyridine-4,4'-dicarboxylic acid was purchased from Sigma-Aldrich and Pyridyl-pyrazolyl carboxylic acid preparation was described earlier ${ }^{[11]}$. HPLC was performed at room temperature on a Shimadzu liquid chromatograph 
equipped with UV-Vis detector and column oven. HPLC was done on a EC $250 \times 4.6 \mathrm{~mm}$ Nucleosil 300-5 C4. Gradients of $\mathrm{CH}_{3} \mathrm{CN}$ (solvent B) and $0.1 \mathrm{M}$ triethylammoniumacetate in water (solvent A) were used: $1 \mathrm{~min}$ at $0 \% \mathrm{~B}$; in $20 \mathrm{~min}$ from $0 \%-30 \% \mathrm{~B}$; in $6 \mathrm{~min}$ from $30 \%$ $90 \% \mathrm{~B} ; 10 \mathrm{~min}$ at $90 \% \mathrm{~B}$.

\section{Synthesis of oligo 4}



PG: Cytidine - benzoyl protected

Adenosine - benzoyl protected 
Guanosine - isobutyryl protected

Scheme 2: Synthesis of oligo 4; the 3'-TFA(Trifluoracetic acid) protected C7-aminolink and 5'- MMT protected C6-aminolink hairpin-DNA on a CPG solid support was purchased from Metabion, Planegg-Martinsried (Germany). 1-Pyrenebutyric acid N-hydroxysuccinimide ester was purchased from Sigma-Aldrich. 1-Hydroxybenzotriazole (HOBT) was purchased from

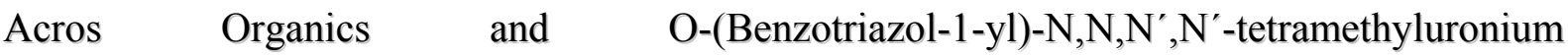
hexafluorphosphate (HBTU) was purchased from Fluka. The preparation of the ligand Pyridyl-pyrazolyl carboxylic acid was described earlier ${ }^{[11]}$. HPLC was performed at room temperature on a Shimadzu liquid chromatograph equipped with UV-Vis detector and column oven. HPLC was done on a EC 250 x $4.6 \mathrm{~mm}$ Nucleosil $300-5 \mathrm{C} 4$. Gradients of $\mathrm{CH}_{3} \mathrm{CN}$ (solvent $\mathrm{B}$ ) and $0.1 \mathrm{M}$ triethylammoniumacetate in water (solvent $\mathrm{A}$ ) were used: $1 \mathrm{~min}$ at $0 \%$ $\mathrm{B}$; in $20 \mathrm{~min}$ from $0 \%-30 \% \mathrm{~B}$; in $6 \mathrm{~min}$ from $30 \%-90 \% \mathrm{~B}$; $10 \mathrm{~min}$ at $90 \% \mathrm{~B}$. 
MALDI-mass spectra of oligo 1, oligo2, oligo 3 and oligo 4

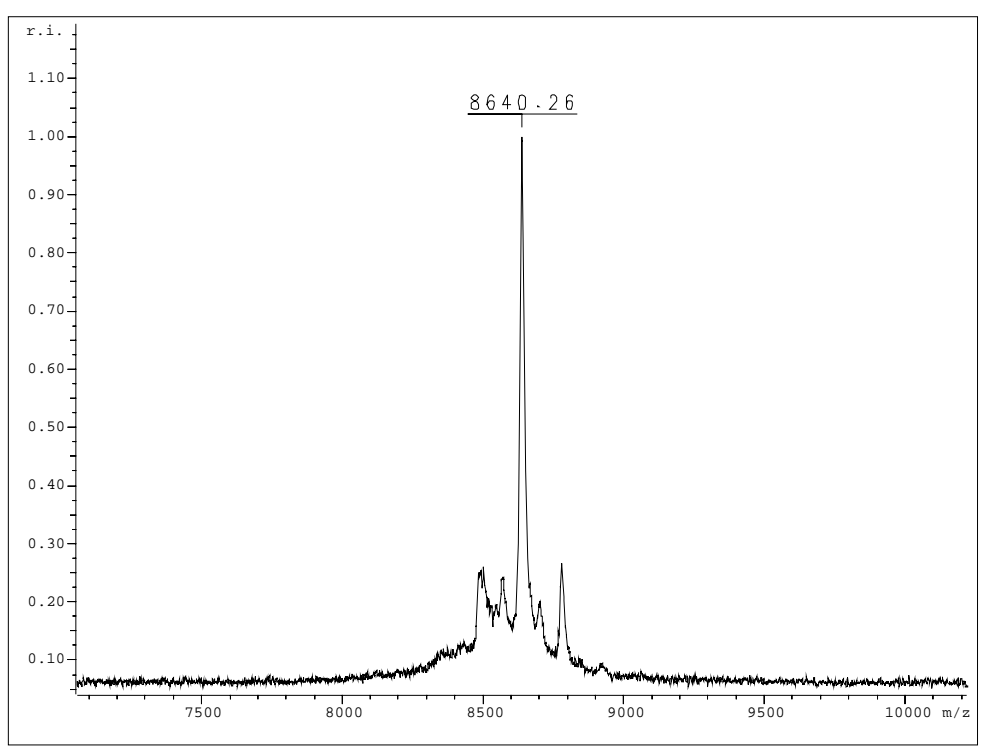

Figue 1: MALDI Spectrum of oligo $1 \mathrm{M}_{\text {calc }}=8638\left(\mathrm{M}-\mathrm{H}^{+}\right) ; \mathrm{M}_{\text {found }}=8640$

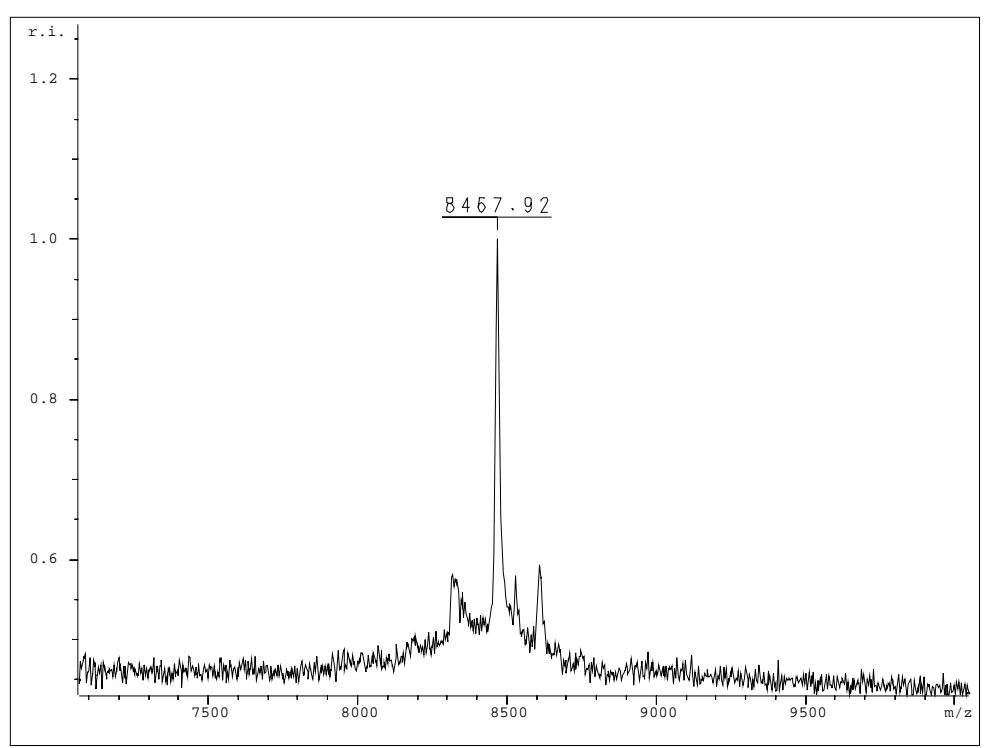

Figure 2: MALDI Spectrum of oligo $2 \mathrm{M}_{\text {calc }}=8467\left(\mathrm{M}-\mathrm{H}^{+}\right) ; \mathrm{M}_{\text {found }}=8468$ 


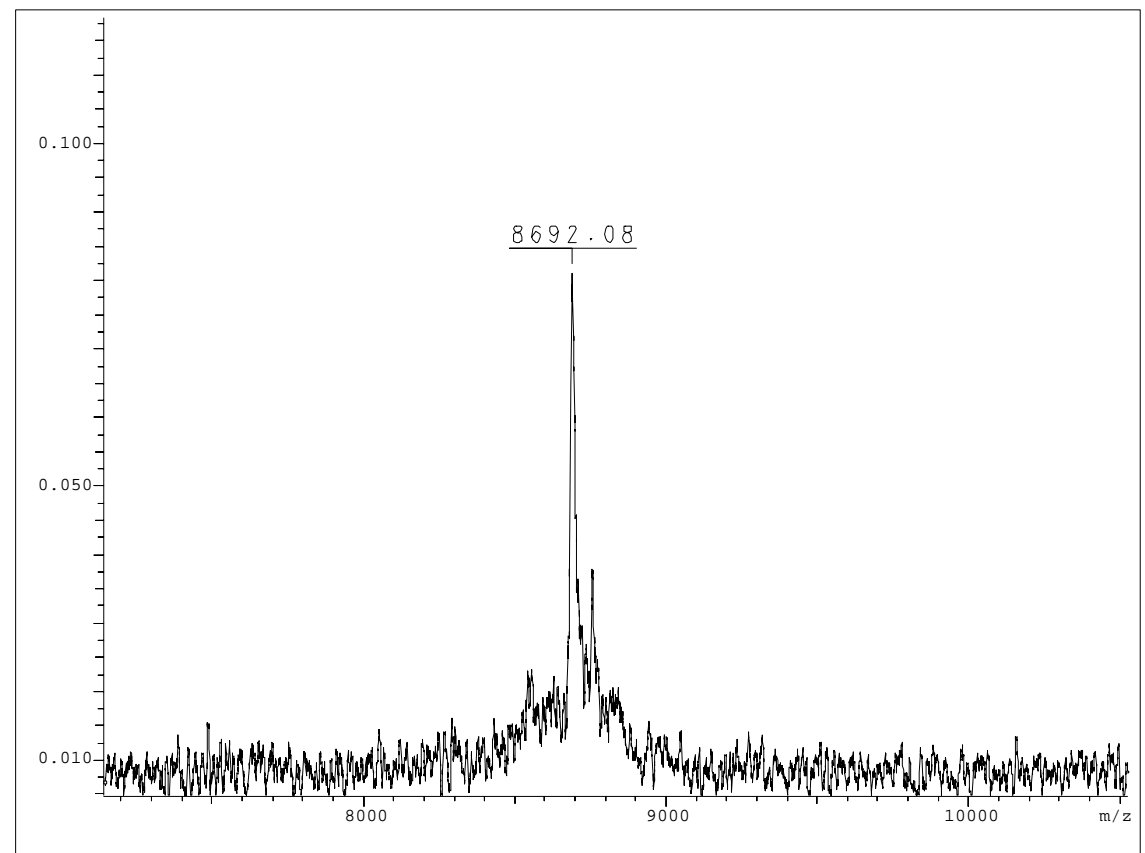

Figure 3: MALDI Spectrum of oligo $3 \mathrm{M}_{\text {calc }}=8691\left(\mathrm{M}-\mathrm{H}^{+}\right) ; \mathrm{M}_{\text {found }}=8692$

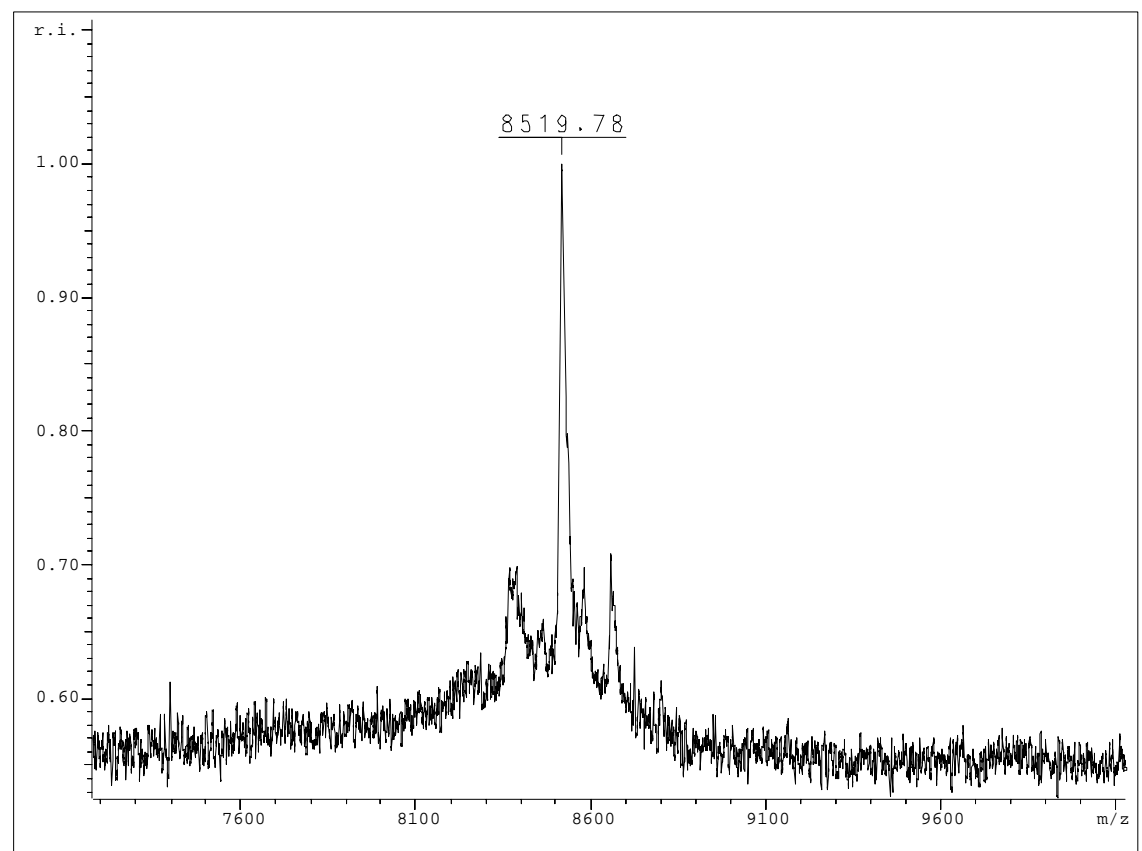

Figure 4: MALDI Spectrum of oligo $4 \mathrm{M}_{\text {calc }}=8516\left(\mathrm{M}-\mathrm{H}^{+}\right) ; \mathrm{M}_{\text {found }}=8520$ 


\section{Fluorescence recovery of $\mathrm{Cu}(\mathrm{II})$ quenched 1 by competing ligand 1,2-}

\section{diaminoethane}

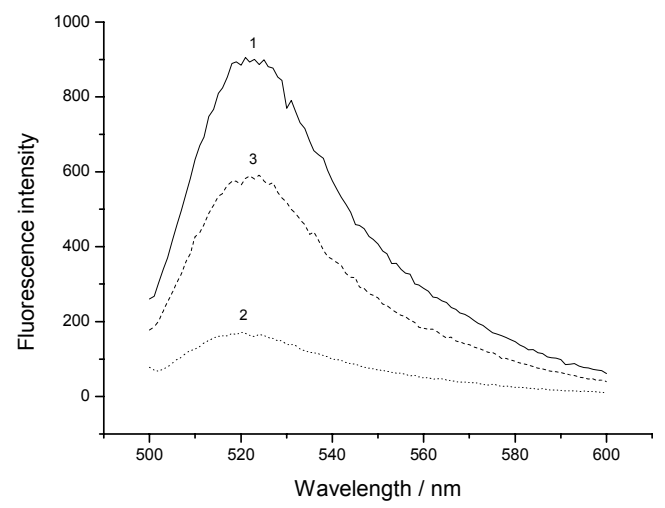

Figure 5: Fluorescence intensities: $0.1 \mu \mathrm{M}$ oligo 1 (1), addition of $5 \mu \mathrm{M} \mathrm{Cu}(\mathrm{II}) \mathrm{SO}_{4}$ (2), addition of $5 \mu \mathrm{M}$ 1,2-diaminoethane (3), $10 \mathrm{mM}$ MOPS pH 7, $1 \mathrm{M} \mathrm{NaCl}, \mathrm{T}=25^{\circ}$

We suggest that the quenching process is triggered by intramolecular coordination of a phenolate donor of fluorescein, which is more basic and therefore a better donor than carboxylate [1], to a free coordination site of the (pypz) $\mathrm{Cu}^{2+}$ moiety of $\mathbf{1}$. This is indicated by $58 \%$ recovery of fluorescence when 1,2-diaminoethane (en, $5 \mu \mathrm{M}$ ) is added to the solution containing $5 \mu \mathrm{M} \mathrm{Cu}^{2+}$ and $0.1 \mu \mathrm{M}$ 1. Formation of a ternary complex $\left[\mathrm{Cu}^{2+}(\mathbf{1})(\mathrm{en})\right]$ is expected which compares well to the complex $\left[\mathrm{Cu}^{2+}\left(2,2^{\prime}\right.\right.$-bipyridine $\left.)(\mathrm{en})\right]$ for which crystallographic [2] data are available: the four in-plane sites of copper are blocked by the two bidentate chelators and not available for coligand coordination. $58 \%$ quenching-inactive ternary complex $\left[\mathrm{Cu}^{2+}(\mathbf{1})(\mathrm{en})\right]$ and $42 \%$ quenching active $\left[\mathrm{Cu}^{2+}(\mathbf{1})\right]$ fit a calculated species distribution using published stability data of the en/ $\mathrm{Cu}^{2+}$ system [3], a $\mathrm{Cu}^{2+}(\mathbf{1})$ formation constant $\log \mathrm{K}=6.3$ (see above), and assuming for the association of $\mathbf{1}$ and $\mathrm{Cu}^{2+}(\mathrm{en})$ a $\operatorname{logK}$ value of 5.9, somewhat smaller than the $\mathrm{Cu}^{2+}$ binding constant of $\mathbf{1}$ [4].

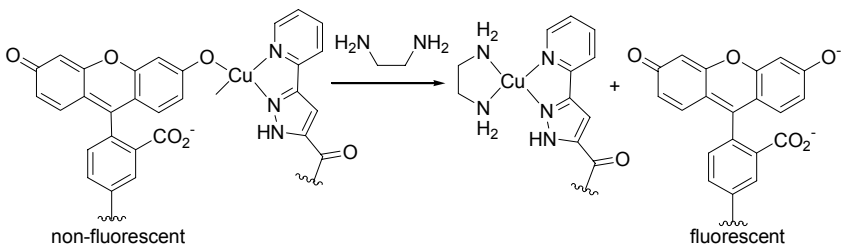

Fluorescence quenching by intramolecular fluorescein coordination at $\mathrm{Cu}^{2+}(\mathbf{1})$

[1] At $\mathrm{pH} 7$ the nonfluorescent carboxylate monoanion $\left(\mathrm{pK}_{\mathrm{a}}=4.3\right)$ of fluorescein is in equilibrium with the strongly fluorescent carboxylate+phenolate dianion, $\mathrm{pKa}=6.7$ at $21^{\circ} \mathrm{C}$ and $70 \mathrm{mM} \mathrm{NaCl}, \mathrm{S}$. A. Smith, W. A. Pretorius, Water $S A, \mathbf{2 0 0 2}, 28,395-402$.

[2] C. C. Su, Y. L. Lin, S. J. Liu, T. H. Chang, S. L. Wang, L. F. Liao, Polyhedron, 1993, 12, 2687-2696.

[3] R. Griesser, H. Sigel, Inorg. Chem., 1970, 9, 1238-1243. The program „Species Ver. 1.2” by L.D. Pettit, Academic Software 1999, was used for calculation of species distribution.

[4] This is a reasonable assumption since the association constant for $2,2^{\prime}$ '-bipyridine and $\mathrm{Cu}^{2+}(\mathrm{en})$ is $1.2 \operatorname{logK}$ values smaller than for 2,2'-bipyridine and $\mathrm{Cu}^{2+}(\operatorname{logK}=8)$ [3]. 
Fluorescence of $\mathrm{Cu}(\mathrm{II})$ quenched oligo 2 on addition of complementary DNA 1

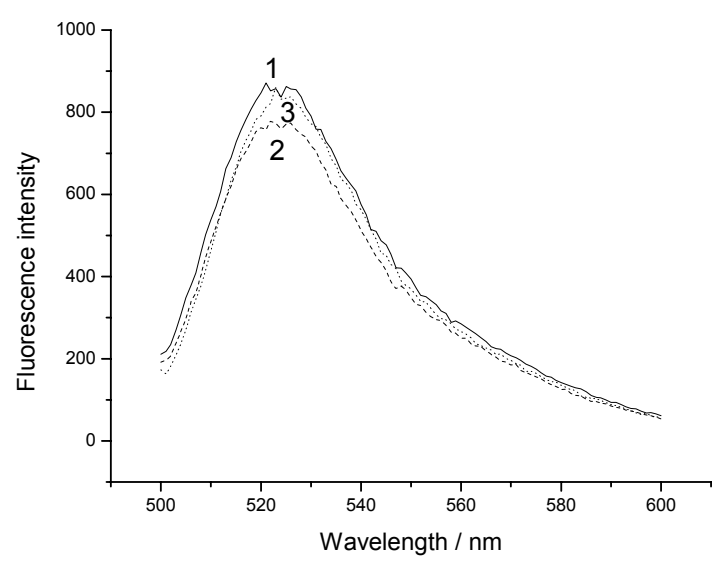

Figure 6: Quenching experiments with oligo 2: $0.1 \mu \mathrm{M}$ oligo 2 (1), addition of $5 \mu \mathrm{M}$ $\mathrm{Cu}(\mathrm{II}) \mathrm{SO}_{4}$ (2), addition of $0.5 \mu \mathrm{M}$ DNA 1 (3); $10 \mathrm{mM}$ MOPS pH7, $1 \mathrm{M} \mathrm{NaCl}, \mathrm{T}=25^{\circ}$

Only $5 \%$ quenching was observed for oligo 2 after addition of $\mathrm{CuSO}_{4}$ due to unspecific coordination of $\mathrm{Cu}^{2+}$ Ions to nucleobases. 
Fluorimetric titrations of oligo 1, oligo 2, oligo 3 and oligo 4 with $\mathrm{Cu}$ (II)
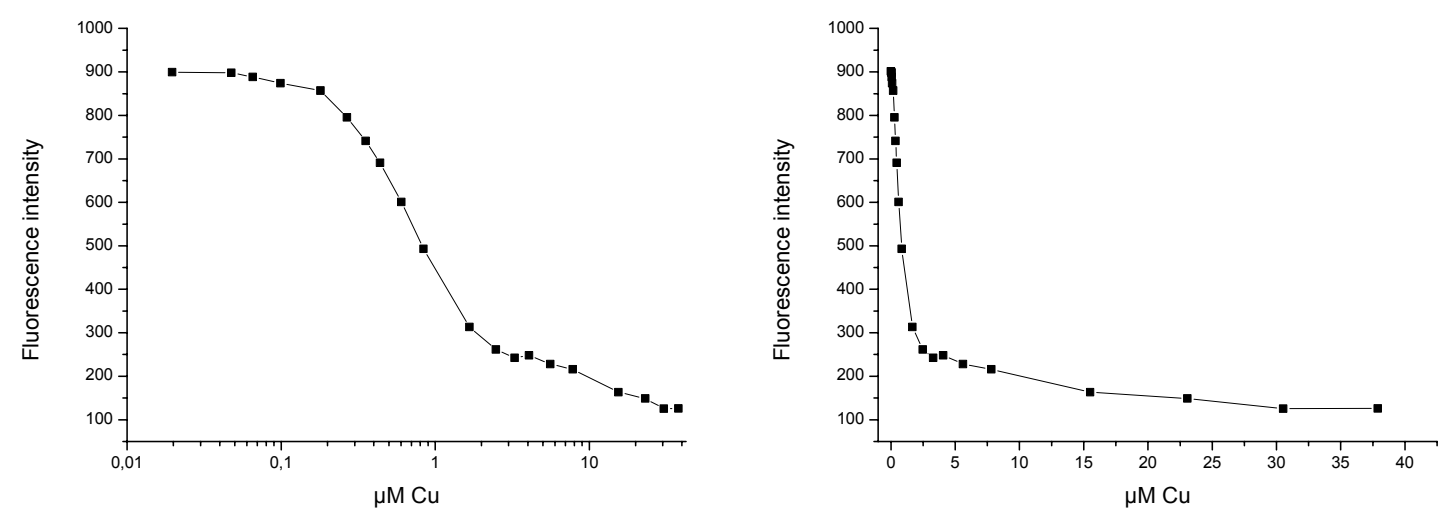

Figure 7: Fluorimetric titration (excitation at $\lambda=494 \mathrm{~nm}$, emission at $\lambda=522 \mathrm{~nm}$ ) of oligo 1 $(0.1 \mu \mathrm{M})$ with $\mathrm{CuSO}_{4}$, logarithmic scale (left), linear scale (right). $10 \mathrm{mM}$ MOPS pH 7, $1 \mathrm{M}$ $\mathrm{NaCl}, \mathrm{T}=25^{\circ}$
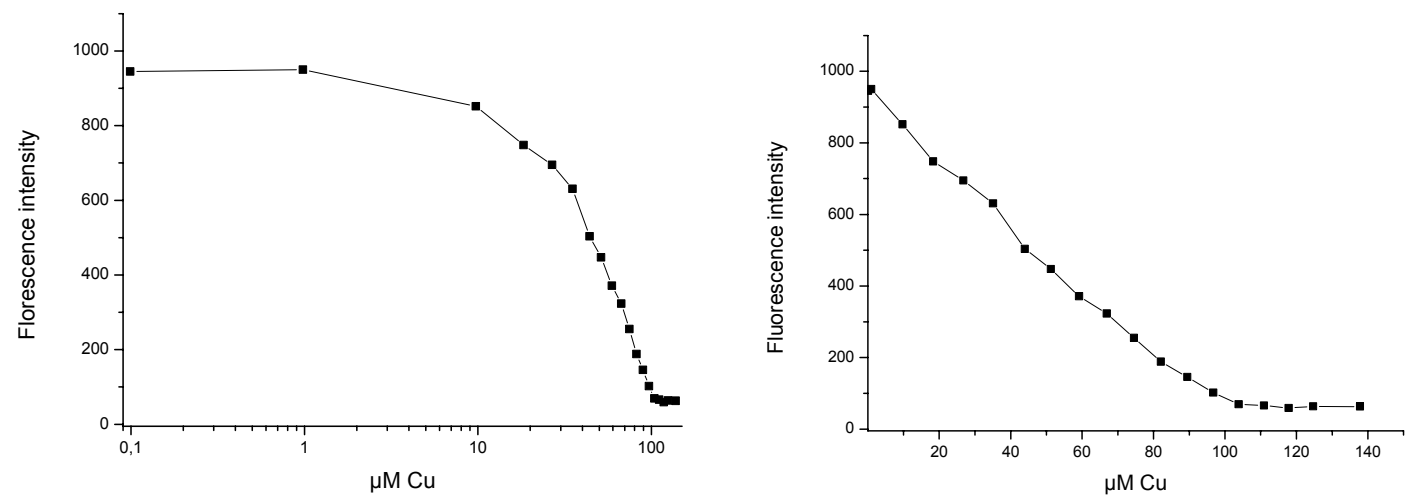

Figure 8: Fluorimetric titration (excitation at $\lambda=494 \mathrm{~nm}$, emission at $\lambda=522 \mathrm{~nm}$ ) of oligo 2 $(0.1 \mu \mathrm{M})$ with $\mathrm{CuSO}_{4}$, logarithmic scale (left), linear scale (right). $10 \mathrm{mM}$ MOPS pH 7, $1 \mathrm{M}$ $\mathrm{NaCl}, \mathrm{T}=25^{\circ}$ 

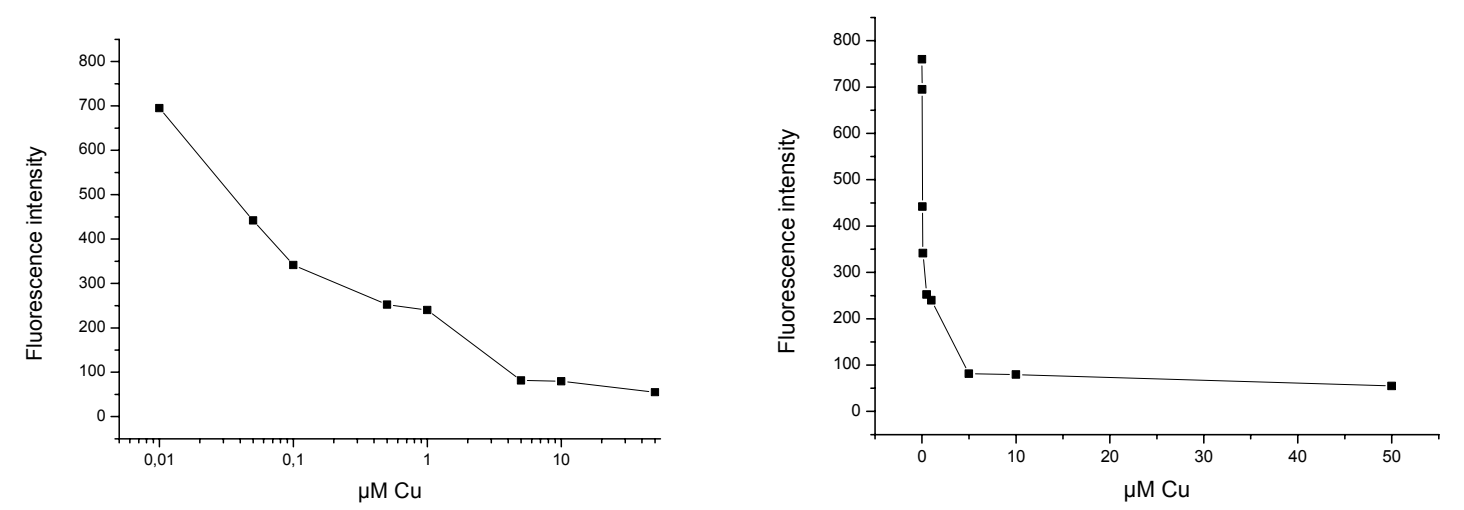

Figure 9: Fluorimetric titration (excitation at $\lambda=494 \mathrm{~nm}$, emission at $\lambda=522 \mathrm{~nm}$ ) of oligo 3 $(0.1 \mu \mathrm{M})$ with $\mathrm{CuSO}_{4}$, logarithmic scale (left), linear scale (right). $10 \mathrm{mM}$ MOPS pH 7, $1 \mathrm{M}$ $\mathrm{NaCl}, \mathrm{T}=25^{\circ}$
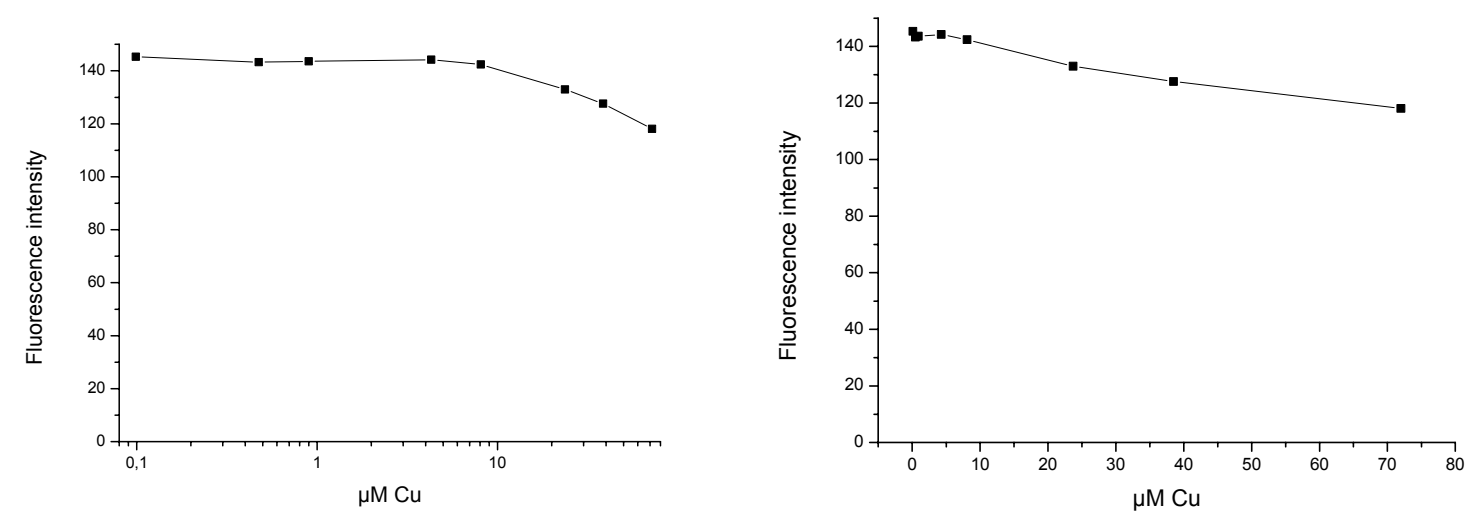

Figure 10: Fluorimetric titration (excitation at $\lambda=340 \mathrm{~nm}$, emission at $\lambda=381 \mathrm{~nm}$ ) of oligo 4 $(0.1 \mu \mathrm{M})$ with $\mathrm{CuSO}_{4}$, logarithmic scale (left), linear scale (right). $10 \mathrm{mM} \mathrm{MOPS} \mathrm{pH} \mathrm{7,1} \mathrm{M}$ $\mathrm{NaCl}, \mathrm{T}=25^{\circ}$ 
Fluorimetric and photometric titrations of calcein and oligo 1 with $\mathrm{Cu}(\mathrm{II})$

\section{Calcein}<smiles></smiles>
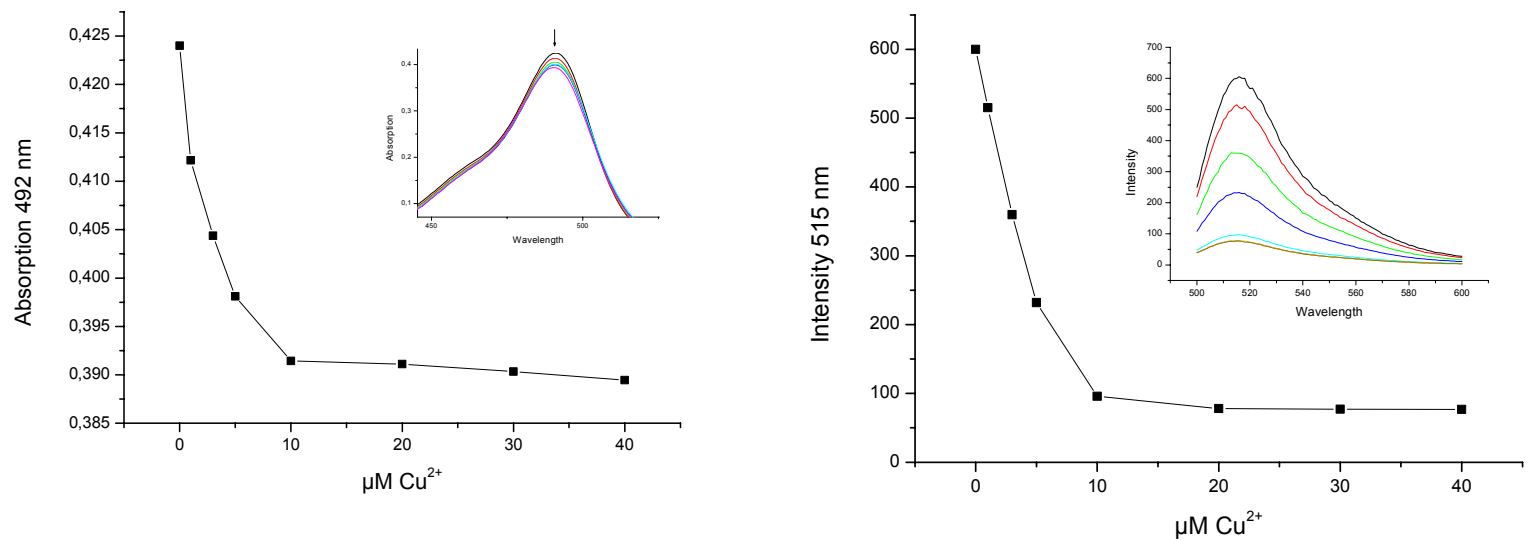

Figure 11: top: Structure of Calcein; bottom left: Copper(II) titration absorption measurement of Calcein; bottom right: Copper(II) titration fluorescence measurement of Calcein; $10 \mu \mathrm{M}$ Calcein, $10 \mathrm{mM}$ MOPS pH7, $1 \mathrm{M} \mathrm{NaCl}, \mathrm{T}=25^{\circ} \mathrm{C}$
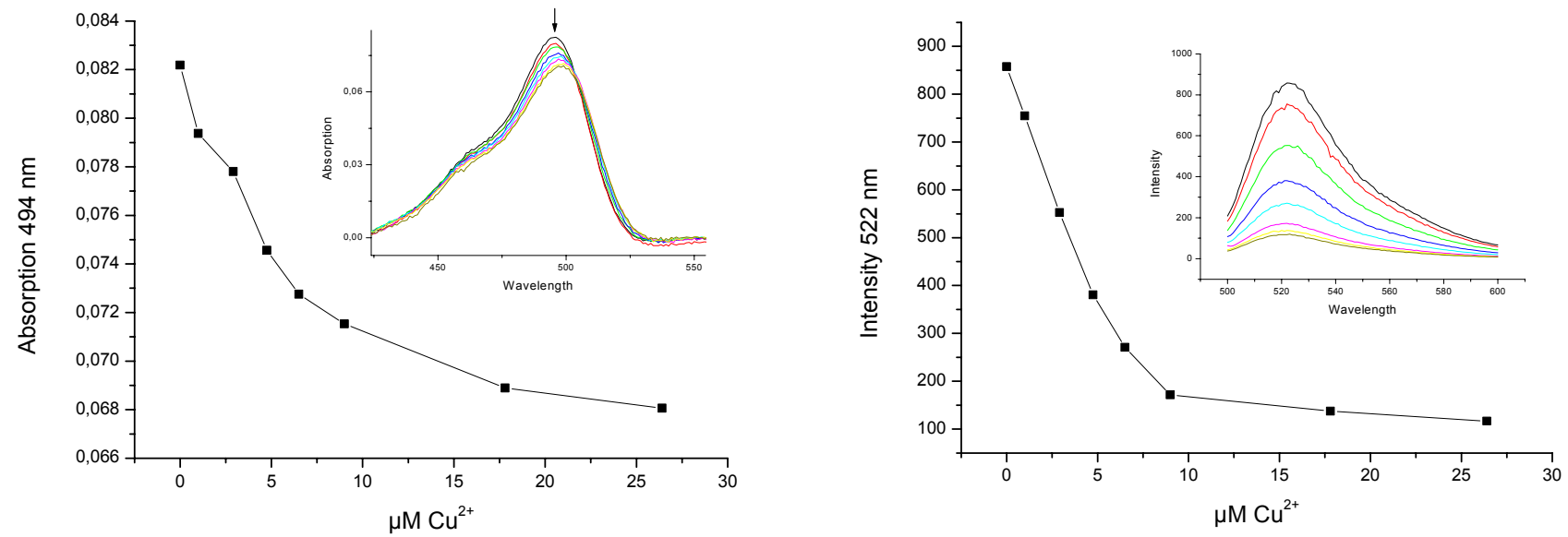

Figure 12: left: Copper(II) titration absorption measurement; right: Copper(II) titration fluorescence measurement; $5 \mu \mathrm{M}$ oligo1, $10 \mathrm{mM}$ MOPS pH7, $1 \mathrm{M} \mathrm{NaCl}, \mathrm{T}=25^{\circ} \mathrm{C}$ 
Absorption and fluorescence spectra of calcein (Fig. 7) and oligo 1 (Fig. 8) show similar decrease of absorption and fluorescence after adition of $\mathrm{CuSO}_{4}$. In case of strong $\mathrm{Cu}^{2+}$ binder Calcein, a 1:1 complex is apparently formed quantitatively on addition of 1 equivalent metal ion $(=10 \mu \mathrm{M})$. In case of oligo $\mathbf{1}$, decrease of optical optical absorbance and fluorescence is more sluggish due to weaker $\mathrm{Cu}(\mathrm{II})$ binding by the pyridyl-pyrazole chelator. 